\title{
EVALUASI KUALITAS MARKETPLACE ABC.COM BERDASARKAN KERANGKA KERJA KEPUASAN PENGGUNA, WEBQUAL 4.0 DAN IMPORTANCE PERFORMANCE ANALYSIS (IPA)
}

\author{
Aditya Rachmadi ${ }^{1}$, Admaja Dwi Herlambang ${ }^{2}$, Nozomi Alifia Ghaisani ${ }^{3}$ \\ Fakultas Ilmu Komputer, Jurusan Sistem Informasi, Universitas Brawijaya \\ E-mail : rachmadiaditya@ub.ac.id, herlambang@ub.ac.id,nozomikurniawan@gmail.com
}

\begin{abstract}
Competition between companies especially in e-commerce is increasingly fierce nowadays. ABC.com is a website that provides marketplace service, by providing better website it can improve service for their customer. This study aim to identify and prioritize factors that affect marketplace quality at ABC.com. The research approach used is quantitative approach with descriptive analysis. Sample selected from the population of user who have ABC.com account that amount to total $1.700 . .000$ registered user Sampling method used is convenience sampling that provide 109 respondent. Data collection is done through a questionnaire and provide factors that affect marketplace namely usability, information quality, service interaction quality, and user satisfaction. These factors is in the high category especially in indicator transaction and information security that placed in the A quadrant. While other indicators like performance, timeliness, purchase satisfaction and experience satisfaction placed in low priority (C quadrant). Recommendation for this study are ABC.com should increase their transaction process, information security and performance to obtain customer satisfaction in purchase activities that drive experience satisfaction.
\end{abstract}

Keywords : e-commerce, website quality, marketplace, Webqual, Importance Performance Analysis

\section{PENDAHULUAN}

Persaingan penjualan secara online semakin meningkat terutama pada website e-commerce di Indonesia. Perusahaan yang bergerak di bidang $e$ commerce, diharuskan untuk berlomba dalam memberikan pelayanan yang terbaik, memberikan tampilan website yang menarik dan memberikan layanan serta informasi yang akurat sehingga calon konsumen tidak ragu dalam melakukan transaksi. Kualitas website yang baik akan membuat calon konsumen merasa puas dalam menggunakan website, pengguna yang merasa puas akan terpicu untuk menggunakan website yang sama dalam melakukan transaksi.

ABC.com adalah online marketplace hasil joint venture antara Telkom Indonesia dengan eBay yang bernaung dibawah payung PT. Metraplasa dan resmi diluncurkan pada tanggal 08 Desember 2014. Visi dan misi dari ABC.com adalah membesarkan UKM, menjadi satu-satunya tempat membeli produk impor dari Amerika, Eropa dan sebagainya, serta membesarkan individual-individual seller di Indonesia.

Berdasarkan hasil wawancara dengan stakeholder yang didukung dengan observasi, ABC.com mengalami permasalahan tampilan yaitu peletakan kolom pencarian yang terlalu kecil sehingga pengguna kesulitan menemukan kolom pencarian saat ingin melakukan pencarian produk. Permasalahan juga terjadi pada kualitas informasi yang dapat diakses pengguna. Informasi stok produk seringkali tidak sesuai antara informasi yang disediakan oleh website dengan informasi dari penjual.

WebQual 4.0 merupakan kerangka kerja yang dapat digunakan untuk dapat mendeskripsikan kualitas sebuah website dilihat dari faktor usability, information quality, service interaction quality, dan user satisfaction. Permasalahan pada ABC.com ternyata selaras dengan faktor-faktor WebQual terutama usability dan information quality. Penelitian ini memiliki tujuan untuk mendeskripsikan kualitas website berdasarkan kondisi atau faktor-faktor tertentu. Kesesuaian antara permasalahan dan tujuan dari penelitian menjadikan WebQual 4.0 sebagai kerangka kerja yang sesuai untuk pengukuran kualitas website ABC.com. Important Performance Analysis (IPA) digunakan untuk mengkategorikan permasalahan pada tiap faktor menjadi prioritas perbaikan, berdasarkan analisis IPA akan ditentukan rekomendasi perbaikan.

Hyeong dan Niehm membagi dimensi kualitas website menjadi lima, yaitu informasi, meliputi kualitas konten, kegunaan, kelengkapan, akurat, dan relevan; keamanan meliputi kepercayaan; privasi dan jaminan keamanan; kemudahan, meliputi mudah untuk dioperasikan, mudah dimengerti, dan kecepatan; kenyamanan, meliputi daya tarik visual, daya tarik emosional, desain kreatif dan aktraktif; dan kualitas pelayanan, meliputi kelengkapan secara online, dan customer service (3). 


\section{METODE}

Alur dari metode penelitian dapat dilihat dalam Gambar 2 alur penelitian yang diadaptasi dari Hasibuan (4).

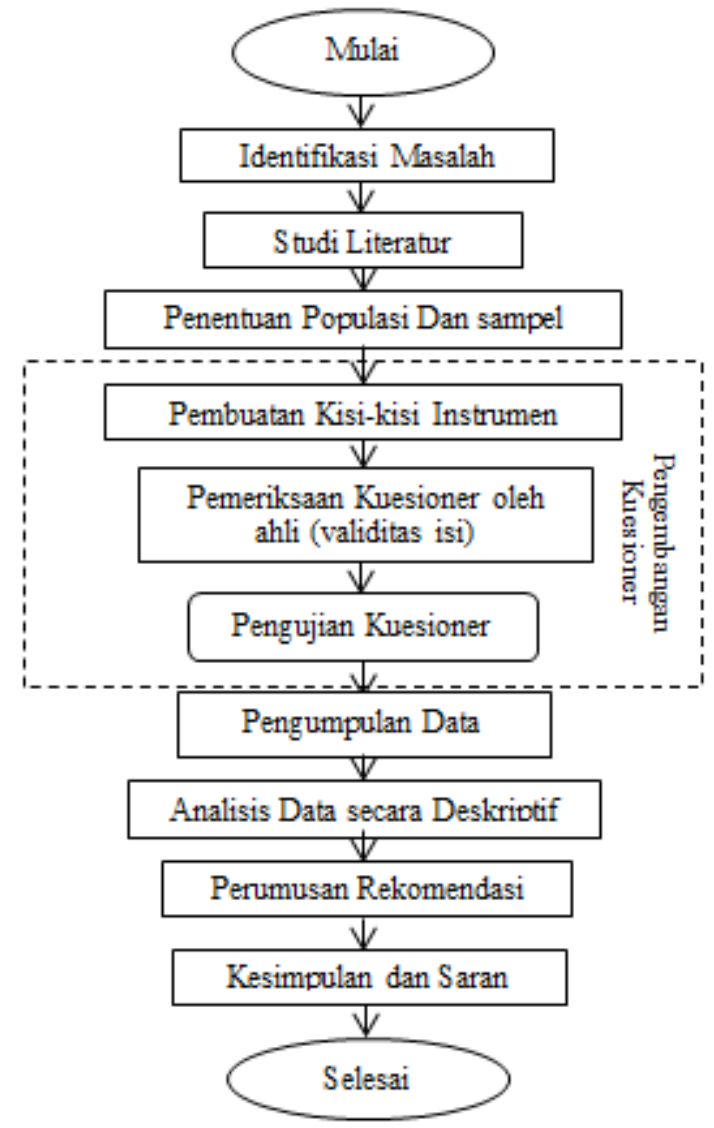

\section{Gambar 1. Analisis Kuadran IPA variabel usability}

Identifikasi masalah dilakukan pada ABC.com serta dilakukan studi pendahuluan terhadap pengguna ABC.com sehingga didapatkan masalah yang akan diteliti. Studi literatur dilaksanakan dengan tujuan untuk mencari referensi-referensi yang berkaitan dengan penelitian sejenis yang pernah dilakukan. Pada penelitian ini,sampel yang diambil adalah beberapa pengguna/konsumen yang pernah bertransaksi menggunakan situs ABC.com. Total member yang telah teregistrasi pada website Blanja.com pada Februari 2018 adalah 1.7 juta pengguna. Penentuan jumlah sampel pada penelitian ini menggunakan rumus Slovin.

Berdasarkan perhitungan rumus slovin tersebut, dapat diketahui sampel yang dibutuhkan untuk penelitian ini adalah minimal 99.99 (dibulatkan menjadi 100). Jumlah responden yang didapatkan sebesar 109 orang. Teknik pengambilan sampel yang digunakan dalam penelitian ini adalah convenience sampling.

Kuesioner tertutup digunakan dalam pengembangan kuesioner dengan skala likert lima poin dan pernyataan-pernyataan yang terdapat dalam kuesioner berdasarkan indikator-indikator pada variabel Webqual 4.0, yaitu usability, information quality, service interaction quality, serta penambahan indikator-indikator pada variabel user satisfaction.

Selanjutnya dilakukan validasi kepada dua ahli dengan cara menilai tiap-tiap pernyataan dengan skala 1 (kurang sesuai dengan indikator) sampai 5 (telah sesuai dengan indikator) dan didapatkan hasil penilaian yang kemudian dihitung menggunakan rumus Aiken's V (1).

Hasil validasi selanjutnya akan menjadi acuan dalam mengeliminasi pernyataan yang belum valid. Selanjutnya dilakukan pilot study pada 30 responden dan dilakukan uji validitas dan reliabilitas.

Penyebaran dilakukan melalui media sosial. Pengumpulan data melalui wawancara kepada Vice President Ops \& CM serta membagikan kuesioner kepada responden yang pernah bertransaksi di ABC.com. Kemudian hasil kuesioner yang didapatkan akan dilakukan analisis data menggunakan statistik deskriptif yang sebelumnya dilakukan uji asumsi klasik berupa uji normalitas, uji homogenitas, dan uji linearitas. Pada statistik deskriptif dilakukan perhitungan pemusatan data dan penyebaran data. Kemudian data dilakukan analisis IPA, yaitu analisis tingkat kesesuaian, tingkat kesenjangan (gap), dan analisis kuadran. Dari hasil kuadran IPA didapatkan indikator apa yang telah sesuai dengan keinginan pengguna dan apa saja yang perlu diperbaiki serta memberikan rekomendasi yang dapat dilakukan oleh perusahaan. Kemudian ditarik simpulan dari penelitian ini dan memberikan saran terhadap penelitian selanjutnya.

\section{PEMBAHASAN \\ a. Usability}

Berdasarkan hasil perhitungan statistik deskriptif, keseluruhan indikator pada variabel usability berada dalam kategori tinggi yaitu $76 \%$ pada tingkat kinerja dan $78.35 \%$ pada tingkat kepentingan. Nilai tingkat kesesuaian dari variabel usability masih belum sesuai dengan yang diharapkan dengan pengguna karena nilai kurang dari $100 \%$. Tingkat kesenjangan masih bernilai negatif. Dari hasil analisis tingkat kesesuaian dan kesenjangan dari variabel usability dapat dikatakan bahwa kinerja marketplace ABC.com masih belum sesuai dengan harapan dari sisi pengguna.

Berdasarkan analisis IPA, indikator appearance, ease of use, navigation berada pada kuadran B (keep up the good work/pertahankan). Indikator-indikator yang berada dalam kuadran ini memiliki nilai yang tinggi pada tingkat kinerja maupun tingkat kepentingan sehingga pada indikator ini tidak diperlukan perbaikan kualitas appearance, ease of use dan navigation dan pihak ABC.com dapat mempertahankan prestasi kinerja yang telah dicapai sebagai atribut penunjang kepuasan pelanggan. 
Berdasarkan analisis IPA, indikator performance berada pada kuadran C (low priority/prioritas rendah) sehingga tidak perlu dilakukan perbaikan kualitas pada indikator ini karena dianggap kurang penting oleh pengguna dan pelayanannya kurang memuaskan. Dengan demikian, rekomendasi yang dapat diberikan untuk meningkatkan indikator ini adalah memanfaatkan caching browser; mengkompresi gambar; meminimalkan CSS, HTML, dan JavaScript; mengikuti prinsip above-the-fold principle; dan menerapkan Gzip compression (8). Analisis Kuadran IPA terhadap variabel usability dan indikatornya pada Webqual 4.0, dalam kualitas website ABC.com dapat dilihat dalam Gambar 2.

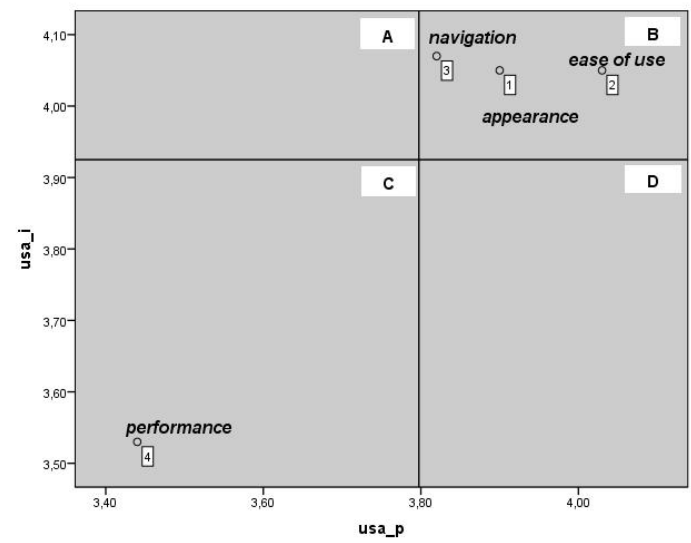

Gambar 2. Analisis Kuadran IPA variabel usability

\section{b. Information Quality}

Berdasarkan hasil perhitungan statistik deskriptif, keseluruhan indikator pada variabel information quality berada dalam kategori tinggi yaitu $77.05 \%$ pada tingkat kinerja dan $81.55 \%$ pada tingkat kepentingan. Nilai tingkat kesesuaian dari variabel information quality masih belum sesuai dengan yang diharapkan dengan pengguna karena nilai kurang dari $100 \%$. Nilai tingkat kesenjangan masih bernilai negatif. Dari hasil analisis tingkat kesesuaian dan kesenjangan dari variabel information quality dapat dikatakan bahwa kinerja marketplace Blanja.com masih belum sesuai dengan harapan dari sisi pengguna. Berdasarkan analisis IPA, indikator accuracy berada pada kuadran B (keep up the good work/pertahankan prestasi). Indikator yang berada tidak diperlukan perbaikan kualitas, pihak ABC.com dapat mempertahankan prestasi kinerja yang telah dicapai sebagai atribut penunjang kepuasan pelanggan.

Berdasarkan analisis IPA, indikator format berada pada kuadran D (posibble overkill/berlebihan). Indikator yang berada pada kuadran ini memiliki tingkat kinerja yang tinggi namun tingkat kepentingannya rendah sehingga kualitas pada indikator ini cenderung berlebihan sehingga tidak diperlukan perbaikan. Berdasarkan analisis IPA, indikator relevancy berada pada kuadran B (keep up the good work/pertahankan prestasi). Pihak Blanja.com dapat mempertahankan prestasi kinerja yang telah dicapai sebagai atribut penunjang kepuasan pelanggan.

Berdasarkan analisis IPA, indikator timeliness berada pada kuadran C (low priority/prioritas rendah) sehingga tidak perlu memprioritaskan perbaikan kualitas pada indikator ini karena dianggap kurang penting oleh pengguna dan pelayanannya kurang memuaskan. Rekomendasi yang dapat diberikan pada indikator ini adalah pihak Blanja.com selalu memberikan informasi yang terbaru dan tepat waktu pada website ABC.com agar dapat meningkatkan kepuasan pengguna. Analisis Kuadran IPA terhadap variabel information quality dan indikatornya pada Webqual 4.0, dalam kualitas website ABC.com dapat dilihat dalam Gambar 3.

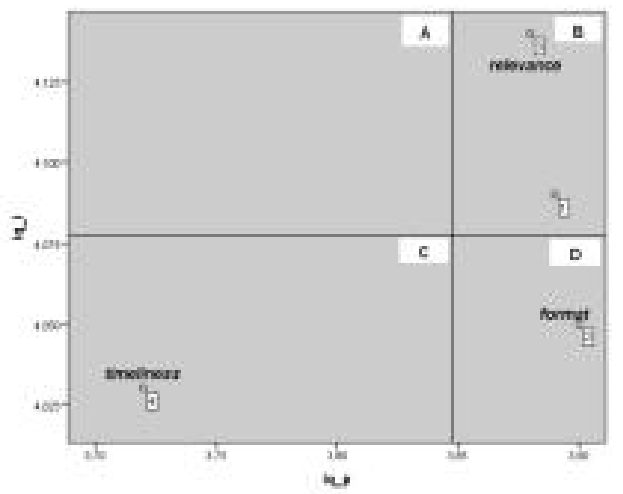

\section{Gambar 3. Analisis Kuadran IPA variabel information quality}

\section{c. Service Interaction Quality}

Berdasarkan hasil perhitungan statistik deskriptif, keseluruhan indikator pada variabel service interaction quality berada dalam kategori tinggi yaitu $75 \%$ pada tingkat kinerja dan $79.67 \%$ pada tingkat kepentingan. Nilai tingkat kesesuaian dari variabel service interaction quality masih belum sesuai dengan yang diharapkan dengan pengguna karena nilai kurang dari $100 \%$. Nilai tingkat kesenjangan masih bernilai negatif. Dari hasil analisis tingkat kesesuaian dan kesenjangan dari variabel service interaction quality dapat dikatakan bahwa kinerja marketplace Blanja.com masih belum sesuai dengan harapan dari sisi pengguna.

Berdasarkan analisis IPA, indikator transaction and information security berada pada kuadran A (concentrate here/prioritas tinggi). Rekomendasi yang dapat diberikan untuk indikator ini adalah mengimplementasikan langkah-langkah pengamanan system seperti public key infrastructure; digital signature; certificate digital; secure socker layer (SSL); transport layer security; dan secure electronic transaction.

Berdasarkan analisis IPA, indikator product delivery berada pada kuadran $\mathrm{B}$ (keep up the good work/pertahankan prestasi). Indikator yang berada 
dalam kuadran ini tidak diperlukan perbaikan kualitas dan pihak ABC.com dapat mempertahankan prestasi kinerja yang telah dicapai sebagai atribut penunjang kepuasan pelanggan.

Berdasarkan analisis IPA, indikator personalization and communication berada pada kuadran C (low priority/prioritas rendah). Rekomendasi yang dapat diberikan pada indikator ini adalah personalisasi layanan membutuhkan 3 hal, yaitu kemauan dan kemampuan dari penyedia layanan untuk dapat menyesuaikan persembahan kepada pelanggan per-individu; menyediakan keinginan yang berbeda dari pelanggan; dan komunikasi (parameter personalisasi) antara pelanggan dan penyedia layanan (6). Gambar 4 merepresentasikan analisis kuadran IPA pada variabel service interaction quality berserta indikatornya

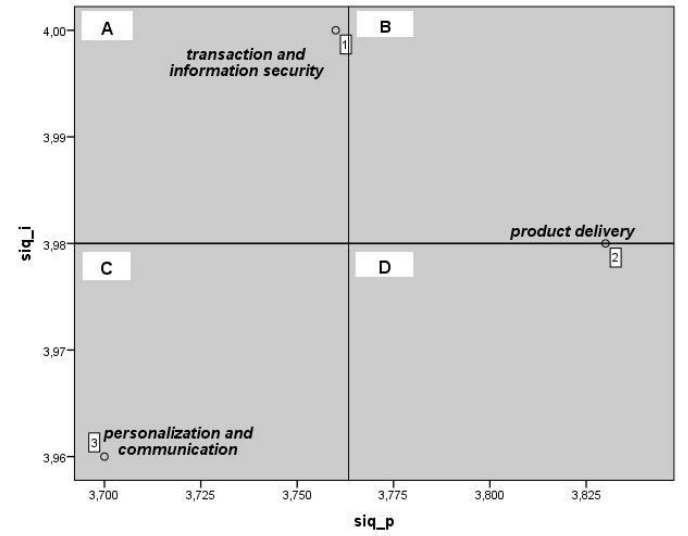

Gambar 4. Analisis Kuadran IPA variabel service interaction quality

\section{d. User Satisfaction}

Berdasarkan hasil perhitungan statistik deskriptif, keseluruhan indikator pada variabel user satisfaction berada dalam kategori tinggi yaitu $77.7 \%$ pada tingkat kinerja dan $80.26 \%$ pada tingkat kepentingan. Nilai tingkat kesesuaian dari variabel user satisfaction masih belum sesuai dengan yang diharapkan pengguna karena memiliki nilai kurang dari $100 \%$. Nilai tingkat kesenjangan masih bernilai negatif. Dari hasil analisis tingkat kesesuaian dan kesenjangan dari variabel user satisfaction dapat dikatakan bahwa kinerja marketplace ABC.com masih belum sesuai dengan harapan dari sisi pengguna.

Berdasarkan analisis IPA, indikator product choice berada pada kuadran B (keep up the good work/pertahankan prestasi) sehingga tidak diperlukan perbaikan kualitas dan pihak ABC.com dapat mempertahankan prestasi kinerja yang telah dicapai sebagai atribut penunjang kepuasan pelanggan. Indikator purchase satisfaction berada pada kuadran C (low priority/prioritas rendah). Rekomendasi yang dapat diberikan pada indikator ini adalah pihak Blanja.com dapat memperhatikan kualitas dan ketersediaan produk; memiliki harga yang bersaing dan metode pembayaran yang beragam sehingga memudahkan pengguna serta pelayanan yang baik kepada pelanggan.

Berdasarkan analisis IPA, Indikator experience satisfaction berada pada kuadran C (low priority/prioritas rendah). Rekomendasi yang dapat diberikan pada indikator ini adalah pihak ABC.com dapat memperhatikan kualitas dan ketersediaan produk; memiliki harga yang bersaing dan metode pembayaran yang beragam sehingga memudahkan pengguna serta pelayanan yang baik kepada pelanggan. Analisis kuadran IPA variabel user satisfaction dapat dilihat pada Gambar 5.

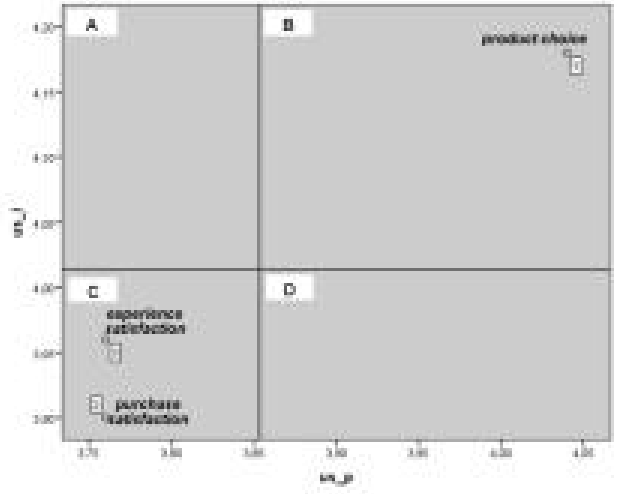

Gambar 5. Analisis Kuadran IPA variabel user satisfaction

\section{KESIMPULAN}

Berdasarkan hasil penelitian mengenai kualitas website Blanja dapat diambil kesimpulan sebagai berikut: variabel yang memiliki priorias untuk dilakukan perbaikan adalah variabel service interaction quality dengan indikator transaction and information security. Selanjutnya prioritas terletak pada kuadran C (low priority/prioritas rendah), apabila pengguna menganggap indikator kuadran $\mathrm{C}$ ini penting karena faktor-faktor eksternal maka pihak ABC.com dipastikan harus melakukan perbaikan terhadap indikator-indikator tersebut. Indikator pada level C antara lain usability, information quality, timeliness, serta personalization and communication.

\section{PUSTAKA}

Akdon \& Riduwan. 2005. Rumus dan Data dalam Aplikasi Statistika. Bandung: Alfabeta.

Barnes, S.J \& Vidgen, R.T. 2002. An Integrative Approach to the Assessment of ECommerce Quality. Journal of Electronic Commerce Research, III, p.114-27.

Budi, R.F. 2013. Pengaruh Kualitas Web terhadap Tingkat Kepuasan Penggunaan Google Scholar (Studi pada Mahasiswa UNAIR 
sebagai Penunjang Kegiatan Akademis). Universitas Airlangga.

Hasibuan, Z.A. 2012. Metodologi Penelitian pada Bidang Ilmu Komputer dan Teknologi Informas, Konsep, Metode, Teknik dan Aplikasi. Depok: Fasilkom Universitas Indonesia

Hyejeong, Kim \& Niehm, L.S. 2009. The Impact of Website Quality on Information Quality, Value, and Loyalty Intentions in Apparel Retailing. Journal of Interactive Marketing, 23, p. 221-133

Jain, K. Bhakar, S. \& Bhakar, S. 2014. Effect of Communication and Personalization on Loyalty with Trust as Mediating Variable. Prestige International Journal of Management \& IT-Sanchayan. 3(1), p. 1-14

Recker, J., 2012. Scientific Research in Information Systems A Beginner's Guide. Queensland: Springer

Garage, Ruby. 2014. How To Improve Website Speed by Optimizing Front-End.

Supranto, J.. 2011. Pengukuran Tingkat Kepuasan Pelanggan untuk Menaikkan Pangsa Pasar. Jakarta: Rineka Cipta. 